\title{
Two New Species of Pseudomonas: P. oryzihabitans Isolated from Rice Paddy and Clinical Specimens and P. luteola Isolated from Clinical Specimens
}

\author{
KENTARO KODAMA, NORIO KIMURA,† AND KAZUO KOMAGATA* \\ Institute of Applied Microbiology, The University of Tokyo, Yayoi 1-1-1, Bunkyo-ku, Tokyo 113, Japan
}

\begin{abstract}
Two new Pseudomonas species which were isolated from rice paddy and clinical specimens (groups Ve-2 and Ve-1) are described. Strains of Pseudomonas oryzihabitans sp. nov. are yellow-pigmented, oxidase-negative, nonsporeforming, gram-negative, polarly monotrichously flagellated, rod-shaped organisms with deoxyribonucleic acid base compositions ranging from 63.9 to $65.6 \mathrm{~mol} \%$ guanine plus cytosine, ubiquinone Q-9, major cellular fatty acids consisting of $C_{18: 1}$ acid, $C_{16: 0}$ acid, and $C_{16: 1}$ acid, and 3-hydroxy acids consisting of 3-OH-C $\mathrm{C}_{10: 0}$ acid and 3-OH-C $\mathrm{C}_{12 ; 0}$ acid. Strains of this species were isolated from rice paddy and clinical specimens (group Ve-2). The type strain of this species is strain KS0036 ( = L-1 = AJ 2197 = IAM 1568 = JCM 2952). Strains of Pseudomonas luteola sp. nov. are yellow-pigmented, oxidase-negative, nonsporeforming, gram-negative, polarly multitrichously flagellated, rod-shaped organisms with deoxyribonucleic acid base compositions ranging from 55.4 to 55.9 mol\% guanine plus cytosine, ubiquinone Q-9, major cellular fatty acids consisting of $C_{18: 1}$ acid, $C_{16: 0}$ acid, and $C_{16: 1}$ acid, and hydroxy acids consisting of 3-OH-C $C_{10: 0}$ acid and 3-OH-C $\mathrm{C}_{12: 0}$ acid. Strains of this species were isolated from clinical specimens (group Ve-1). The type strain of this species is strain KS0921 (= G. L. Gilardi $4239=$ IAM $13000=$ JCM 3352).
\end{abstract}

In the course of a study of the microflora of rice paddies, a large number of yellow-pigmented, gram-negative bacteria were isolated. Some of these organisms were identified as "Pseudomonas lacunogenes," which was studied by Goresline (7), and some characteristics of our isolates have been published previously (12). When we published the characteristics of our strains of " $P$. lacunogenes," the original strains which Goresline used for the description of this species and reference strains were not available from any culture collection or other sources. They are still unavailable. The strains of " $P$. lacunogenes" were a major component of the bacterial flora of normal rice paddies (11). However, this name is not on the Approved Lists of Bacterial Names (26). Recently, we isolated new strains similar to " $P$. lacunogenes" from normal rice paddies. These cultures were oxidase negative and resembled cultures that Weaver et al. (31), Tatum et al. (30), and Gilardi et al. (6) recognized as groups $\mathrm{Ve}-1$ and $\mathrm{Ve}-2$ of yellow-pigmented, oxidative, oxidase-negative, gram-negative, polarly flagellated, rodshaped, bacteria. Therefore, we attempted to identify our isolates from normal rice paddies by using authentic strains representative of groups Ve-1 and Ve-2.

In this paper we describe two new species, Pseudomonas oryzihabitans sp. nov., which was isolated from normal rice paddies and clinical specimens (group Ve-2), and Pseudomonas luteola $\mathrm{sp}$. nov., which was isolated from clinical specimens (group Ve-1).

\section{MATERIALS AND METHODS}

Abbreviations. The following abbreviations are used in this paper: ATCC, American Type Culture Collection, Rockville, Md.; AJ, Central Research Laboratories, Ajinomoto Co., Inc., Kawasaki, Japan; IAM, Institute of Applied Microbiology, University of Tokyo, Tokyo, Japan; JCM, Japan Collection of Microorganisms, The Institute of Physical and

\footnotetext{
* Corresponding author.

† Present address: Research Institute, Morinaga Co. Ltd., Tsurumi-ku, Yokohama 230, Japan.
}

Chemical Research, Wako-shi, Saitama, Japan; NCIB, National Collection of Industrial Bacteria, Torrey Research Station, Aberdeen, United Kingdom; DNA, deoxyribonucleic acid; $\mathrm{G}+\mathrm{C}$, guanine plus cytosine; DNase, deoxyribonuclease; ONPG, $o$-nitrophenyl- $\beta$-galactopyranoside. The designations used for ubiquinones indicate the number of isoprene units in a side chain (e.g., ubiquinones Q-8, Q-9, and Q-10, have 8,9 , and 10 isoprene units, respectively).

Bacterial strains. The strains which we studied are indicated below (names which do not appear on the Approved Lists of Bacterial Names [26] are enclosed in quotation marks). "P. lacunogenes" KS0036 (= L-1 = AJ $2197=\mathrm{IAM}$ $1568=$ JCM 2952), KS0037 (= L-4 = AJ $2201=$ IAM 1601), KS0222 (= L-5 = AJ $2202=$ IAM 1611), KS0901 $(=\mathrm{L}-6=$ AJ 2203), KS0903 (= 2Y-6 = AJ 2209), and KS0904 (= D-2 $=\mathrm{AJ} 2210$ ) were isolated from normal rice paddies by Iizuka and Komagata (12). Strain KS0905 was isolated from Oryza sativa strain C5444 (grain harvested in 1979), strain KS0906 was isolated from $O$. sativa strain C8895 (grain harvested in 1979), strain KS0907 was isolated from $O$. sativa strain C8896 (grain harvested in 1979), strain KS0908 was isolated from Oryza breviligulata strain W1064 (grain harvested in 1977), strain KS0909 was isolated from $O$. sativa strain W0028 (grain harvested in 1977), strain KS0910 was isolated from $O$. sativa strain C5604 (grain harvested in 1975), strain KS0911 was isolated from O. sativa strain C8316, and strain KS0912 was isolated from Oryza perennis strain W492. The above-mentioned yellow pigment-producing strains were newly isolated from flour prepared from rough rice with its hulls removed by using $0.5 \%$ glucose nutrient agar plates at $30^{\circ} \mathrm{C}$ after 5 days of incubation. The following representatives of group Ve-2 were obtained from G. L. Gilardi: strains KS0913 ( = 4438; from an ulcer), KS0914 ( = 4271; from skin), KS0915 (= 4270; from a leg wound), KS0916 (= 4071; from an umbilicus), and KS0917 (= 3987; from a leg wound). Group Ve-1 strains KS0918 (= 4429; from a leg ulcer), KS0919 (= 4420; from skin), KS0920 (= 4249; from a lymph node $), \mathrm{KS}_{0} 921^{\mathrm{T}}\left(=4239^{\mathrm{T}}\right.$; from a wound $)(\mathrm{T}=$ type strain $)$, and $\mathrm{KS} 0922$ (= 4161; from a vagina) were also obtained from 
G. L. Gilardi. Pseudomonas aeruginosa $\mathrm{KS} 0025^{\mathrm{T}}(=\mathrm{ATCC}$ $10145^{\mathrm{T}}=\mathrm{AJ} 2116^{\mathrm{T}}=$ IAM $\left.1514^{\mathrm{T}}\right)$. Pseudomonas maltophilia biovar I strain KS0001 ${ }^{\mathrm{T}}\left(=\mathrm{NCIB} 9203^{\mathrm{T}}=\right.$ ATCC $13637^{\mathrm{T}}=$ AJ $2082^{\mathrm{T}}$ ), and Pseudomonas maltophilia biovar II strain KS0194 (= 2kl; from K. Katoh) $(15,16)$ were used as reference strains. (Swings et al. [28] transferred $P$. maltophilia to the genus Xanthomonas as Xanthomonas maltophilia, but, like other authors $[5,14,15,21,22,32]$, we use the name $P$. maltophilia in this paper.)

Identification methods. Cell form, Gram reaction, motility, and flagellar morphology were determined by using cells grown on $0.5 \%$ glucose nutrient agar containing $0.5 \%$ glucose, $0.5 \%$ peptone, $0.5 \%$ beef extract, $0.25 \% \mathrm{NaCl}$, and $1.5 \%$ agar at $30^{\circ} \mathrm{C}$. Gram staining was carried out by the Hucker-Conn modification (9). Motility was determined by using the hanging drop method, and flagellar morphology was determined by the staining method of Kodaka et al. (17) and by electron microscopy. Granules of poly- $\beta$-hydroxybutyrate were examined in cells cultivated in medium containing $0.02 \%\left(\mathrm{NH}_{4}\right)_{2} \mathrm{SO}_{4}, 0.1 \% \quad \mathrm{KH}_{2} \mathrm{PO}_{4}, 0.05 \%$ $\mathrm{MgSO}_{4} \cdot 7 \mathrm{H}_{2} \mathrm{O}, 0.02 \% \mathrm{KCl}, 0.02 \%$ yeast extract, and $0.05 \%$ DL- $\beta$-hydroxy- $n$-butyrate or $0.5 \%$ sodium succinate by using the staining method of Burdon (3). Production of fluorescent pigment was examined on King $A$ and King $B$ media. Growth on MacConkey agar and SS agar was determined after $24 \mathrm{~h}$ of cultivation. For the oxidation-fermentation test, OF basal medium (catalog no. 0688-01; Difco Laboratories, Detroit, Mich.) was used as the basal medium. Glucose was sterilized by filtration and added at a concentration of $0.5 \%$. The GasPak anaerobic system (BBL Microbiology Systems, Cockeysville, Md.) was used for anaerobic cultures. Catalase activity was detected by the production of bubbles in a $3 \%$ hydrogen peroxide solution. The oxidase test was performed with cytochrome oxidase test paper (Nissui Seiyaku, Tokyo, Japan). Nitrate reduction was tested in nutrient broth containing $0.1 \%, \mathrm{KNO}_{3}$ and succinate-nitrate medium (18). Nitrate respiration (anaerobic growth in the presence of nitrate) was tested by the method of Iizuka and Komagata (13). Urease activity was determined on Christensen medium (4) after incubation for 1 week. DNase activity was determined on DNase agar (Difco) after 1 and 7 days of incubation. Production of indole was determined with Kovac reagent in $1 \%$ tryptone (Difco) broth. Production of hydrogen sulfide was tested on TSI agar for 2 weeks. Hydrolysis of starch was determined by using an iodine solution on nutrient agar containing $0.2 \%$ soluble starch after 1,3 , and 7 days of incubation. Hydrolysis of gelatin was determined in stab cultures in nutrient medium containing $12 \%$ gelatin after 4 weeks of incubation at 20 and $30^{\circ} \mathrm{C}$. Hydrolysis of Tween 80 was determined on nutrient agar containing $0.2 \%$ Tween 80 and $0.01 \% \mathrm{CaCl}_{2}$ after incubation for 1 week (25). Hydrolysis of esculin was determined in nutrient medium supplemented with $0.01 \%$ esculin and $0.05 \%$ ferric citrate: Hydrolysis of ONPG was determined with ONPG disks (Nissui Seiyaku). Both acid and alkaline phosphatase activities were detected by the method of Baird-Parker (1). Phenylalanine deaminase activity was determined in phenylalanine-malonate broth (Nissui Seiyaku). Lysine and ornithine decarboxylases and arginine dihyrolase were detected by the method of Möller (20). Gluconate oxidation was tested by the method of Haynes (8). Utilization of citrate was tested on Simmons citrate agar. Tolerance to sodium chloride was tested in nutrient broth containing $6.5 \% \mathrm{NaCl}$. The methionine requirement was determined by using chemically defined medium (27) supplemented with DL-methionine $(20 \mathrm{mg} / 1,000$ $\mathrm{ml}$ ). Cleavage of protocatechuate was examined by using the
TABLE 1. Morphological and biological characteristics of " $P$. lacunogenes" strains, the new isolates, group Ve-2 strains and group Ve-1 strains ${ }^{a}$

\begin{tabular}{lcccc}
\hline \multicolumn{1}{c}{ Characteristic } & $\begin{array}{c}\text { "P. } \\
\text { lacunogenes" } \\
\text { (six strains) }\end{array}$ & $\begin{array}{c}\text { New } \\
\text { isolates } \\
\text { (eight } \\
\text { strains) }\end{array}$ & $\begin{array}{c}\text { Group } \\
\text { Ve-2 } \\
\text { (five } \\
\text { strains) }\end{array}$ & $\begin{array}{c}\text { Group } \\
\text { Ve-1 } \\
\text { (five } \\
\text { strains) }\end{array}$ \\
\hline Flagellation & & & & \\
Polar, monotrichous & $6 / 6^{b}$ & $8 / 8$ & $5 / 5$ & $0 / 5$ \\
Polar, multitrichous & $0 / 6$ & $0 / 8$ & $0 / 5$ & $5 / 5$ \\
Production of PHB & $3 / 6$ & $2 / 8$ & $2 / 5$ & $4 / 5$ \\
Growth on SS agar & $4 / 6$ & $8 / 8$ & $5 / 5$ & $5 / 5$ \\
OF (glucose), oxidative & $6 / 6$ & $8 / 8$ & $5 / 5$ & $5 / 5$ \\
Nitrate reduction & & & & \\
Nutrient broth & $2 / 6$ & $0 / 8$ & $0 / 5$ & $0 / 5$ \\
containing $\mathrm{KNO} \mathrm{H}_{3}$ & & & & \\
Succinate-NaNO & $4 / 6$ & $0 / 8$ & $0 / 5$ & $4 / 5$ \\
Urease & $5 / 6$ & $8 / 8$ & $5 / 5$ & $4 / 5$ \\
DNase & $0 / 6$ & $0 / 8$ & $2 / 5$ & $4 / 5$ \\
Hydrolysis of: & & & & \\
Gelatin at 20 & $1 / 6$ & $8 / 8$ & $5 / 5$ & $5 / 5$ \\
Gelatin at $30^{\circ} \mathrm{C}$ & $2 / 6$ & $8 / 8$ & $5 / 5$ & $5 / 5$ \\
Esculin & $0 / 6$ & $0 / 8$ & $0 / 5$ & $5 / 5$ \\
ONPG & $0 / 6$ & $0 / 8$ & $0 / 5$ & $5 / 5$ \\
Phosphatase & $0 / 6$ & $0 / 8$ & $0 / 5$ & $5 / 5$ \\
Arginine dihydrolase & $0 / 6$ & $0 / 8$ & $0 / 5$ & $5 / 5$ \\
Gluconate oxidation & $1 / 6$ & $1 / 8$ & $2 / 5$ & $1 / 5$ \\
Tolerance to 6.5\% NaCl & $2 / 6$ & $8 / 8$ & $3 / 5$ & $2 / 5$ \\
Growth at $42^{\circ} \mathrm{C}$ & $6 / 6$ & $8 / 8$ & $0 / 5$ & $5 / 5$ \\
\hline
\end{tabular}

"All strains gave positive results for the following tests: growth on MacConkey agar, production of water-insoluble yellow pigment in cells, and catalase. All strains gave negative results for the following tests: Gram stain, spore formation, oxidase, production of fluorescent pigment, nitrate respiration, production of indole and $\mathrm{H}_{2} \mathrm{~S}$, hydrolysis of starch and Tween 80 , phenylalanine deaminase, lysine and ornithine decarboxylases, methionine requirement, and decomposition of agar. All strains degradated protocatechuate by ortho cleavage.

${ }^{b}$ Number of strains positive/number of strains tested.

c PHB, Poly- $\beta$-hydroxybutyrate.

method of Hugh and Gilardi (10). To study acid production from sugars and sugar alcohols, OF basal medium (Difco) was used as the basal medium. A total of 18 carbon compounds were sterilized by filtration and added at concentrations of $0.5 \%$. To determine the utilization of 29 carbon compounds, chemically defined medium (27) was used as the basal medium. The carbon compounds were used at the following concentrations: $0.2 \%$ for sugars, starch, inulin, and sugar alcohols; $0.1 \%$ for organic acids; and $0.025 \%$ for phenol. Utilization of hydrogen was determined on medium containing $33 \mathrm{ml}$ of $\mathrm{Na}_{2} \mathrm{HPO}_{4}-\mathrm{KH}_{2} \mathrm{PO}_{4}$ buffer $(1 \mathrm{M}, \mathrm{pH} 6.8)$, $1 \mathrm{~g}$ of $\mathrm{NH}_{4} \mathrm{Cl}, 0.5 \mathrm{~g}$ of $\mathrm{MgSO}_{4} \cdot 7 \mathrm{H}_{2} \mathrm{O}, 0.05 \mathrm{~g}$ of $\mathrm{FeCl}_{3} \cdot 6 \mathrm{H}_{2} \mathrm{O}, 0.005 \mathrm{~g}$ of $\mathrm{CaCl}_{2}, 15 \mathrm{~g}$ of agar, and $967 \mathrm{ml}$ of distilled water under an atmosphere containing $80 \%$ hydrogen, $10 \%$ oxygen, and $10 \%$ carbon dioxide at $30^{\circ} \mathrm{C}$ for 2 weeks. " $P$. lacunogenes"' strains KS0036, KS0037, and $\mathrm{KS} 0222$, new isolate KS0905, group Ve-2 strains KS0913 and KS0915, and group Ve-1 strains KS0920 and $\mathrm{KS}_{0921}{ }^{\mathrm{T}}$ were used in the test for hydrogen utilization.

DNA base composition. Cells cultivated in $0.5 \%$ glucose nutrient broth at $30^{\circ} \mathrm{C}$ for $24 \mathrm{~h}$ with shaking were used for DNA analysis. DNA was extracted by the method of Saito and Miura (24), and DNA base composition was calculated from the thermal denaturation temperature of the DNA by using the formula of Marmur and Dotey (19).

Cellular fatty acid composition. Cells cultivated in $0.5 \%$ glucose nutrient broth at $30^{\circ} \mathrm{C}$ for $24 \mathrm{~h}$ with shaking were used for the cellular fatty acid analysis. Cellular fatty acids were liberated from cells by methanolysis with $5 \%$ 
TABLE 2. Acid production from sugars and sugar alcohols and utilization of carbon compounds by " $P$. lacunogenes" strains the new isolates, group Ve-2 strains, and group Ve-1 strains ${ }^{\mathrm{a}}$

\begin{tabular}{lcccc}
\hline \multicolumn{1}{c}{ Characteristic } & $\begin{array}{c}\text { " } P \text {. } \\
\text { (six strains) }\end{array}$ & $\begin{array}{c}\text { New } \\
\text { isolates } \\
\text { (eight } \\
\text { strains) }\end{array}$ & $\begin{array}{c}\text { Group } \\
\text { Ve-2 } \\
\text { (five } \\
\text { strains) }\end{array}$ & $\begin{array}{c}\text { Group } \\
\text { Ve-1 } \\
\text { (five } \\
\text { strains) }\end{array}$ \\
\hline Acid from: & & & & \\
L-Rhamnose & $3 / 6^{b}$ & $8 / 8$ & $3 / 5$ & $5 / 5$ \\
Sucrose & $3 / 6$ & $1 / 8$ & $2 / 5$ & $0 / 5$ \\
Maltose & $6 / 6$ & $8 / 8$ & $5 / 5$ & $4 / 5$ \\
Cellobiose & $0 / 6$ & $4 / 8$ & $0 / 5$ & $0 / 5$ \\
Adonitol & $2 / 6$ & $0 / 8$ & $0 / 5$ & $0 / 5$ \\
Sorbitol & $6 / 6$ & $8 / 8$ & $5 / 5$ & $0 / 5$ \\
Salicin & $0 / 6$ & $0 / 8$ & $0 / 5$ & $5 / 5$ \\
Utilization of: & & & & \\
Citrate (Simmons) & $6 / 6$ & $8 / 8$ & $4 / 5$ & $5 / 5$ \\
D-Ribose & $6 / 6$ & $8 / 8$ & $4 / 5$ & $5 / 5$ \\
Sucrose & $3 / 6$ & $1 / 8$ & $3 / 5$ & $0 / 5$ \\
Glycerol & $6 / 6$ & $8 / 8$ & $4 / 5$ & $5 / 5$ \\
Pyruvate & $6 / 6$ & $8 / 8$ & $4 / 5$ & $5 / 5$ \\
Malonate & $6 / 6$ & $8 / 8$ & $4 / 5$ & $5 / 5$ \\
DL- $\beta$-hydroxy- & $6 / 6$ & $8 / 8$ & $4 / 5$ & $5 / 5$ \\
$\quad$ butyrate & & & & \\
Fumarate & $6 / 6$ & $8 / 8$ & $4 / 5$ & $5 / 5$ \\
2-Ketogluconate & $6 / 6$ & $8 / 8$ & $5 / 5$ & $4 / 5$ \\
o-Hydroxybenzoate & $2 / 6$ & $1 / 8$ & $0 / 5$ & $0 / 5$ \\
m-Hydroxybenzoate & $0 / 6$ & $0 / 8$ & $1 / 5$ & $0 / 5$ \\
\hline
\end{tabular}

${ }^{a}$ All strains gave positive results for the following tests: acid from $\mathrm{L}$ arabinose, D-xylose, D-glucose, D-fructose, D-mannose, D-galactose, trehalose, inositol, and mannitol and utilization of L-arabinose, D-xylose, D-glucose, D-fructose, D-mannose, D-galactose, maltose, trehalose, mannitol, acetate, gluconate, succinate, $p$-hydroxybenzoate, and glutamate. All strains gave negative results for the following tests: acid from lactose and inulin and utilization of lactose, raffinose, inulin, starch, and phenol.

${ }^{b}$ Number of strains positive/number of strains tested.

$\mathrm{HCl}$-methanol (14). Hydroxy acids were separated by thinlayer chromatography by the method of Oyaizu and Komagata (22). Methylated esters were analyzed by gas chromatography, using a model GC-6A chromatograph (Shimadzu, Kyoto, Japan) equipped with a hydrogen flame ionization detector. This instrument contained a capillary column (Diacoat Silar 10C; $0.25 \mathrm{~mm}$ by $30 \mathrm{~m}$; Nippon Chromato, Tokyo, Japan).

Quinone system. Cells cultivated in $0.5 \%$ glucose nutrient broth at $30^{\circ} \mathrm{C}$ for $24 \mathrm{~h}$ with shaking were used for quinone analysis. Quinone systems were determined by the method of Tamaoka et al. (29).

Cytochrome pattern. Cells cultivated in chemically defined medium (27) containing $0.5 \%$ yeast extract (Difco) at $30^{\circ} \mathrm{C}$ for $36 \mathrm{~h}$ with shaking were used to determine the difference spectra of cytochromes. The difference spectra were compared over the range from 390 to $650 \mathrm{~nm}$ by using the method of Stanier et al. (27) and a model UV3000 double-beam recording spectrophotometer (Shimadzu).

\section{RESULTS}

The phenotypic characteristics of the strains studied are shown in Tables 1 and 2 . The six " $P$. lacunogenes" strains, the eight new isolates from normal rice paddies, and the five group Ve-2 strains had the same phenotypic characteristics. The group Ve-1 strains differed from the "P. lacunogenes" strains, the new isolates, and the group Ve-2 strains in some phenotypic characteristics.

Phenotypic characteristics of " $P$. lacunogenes" strains, new isolates, and group Ve-2 strains. The 19 strains studied were nonsporeforming, gram-negative, rod-shaped organisms measuring 0.7 to 1.0 by 1.5 to $2.5 \mu \mathrm{m}$; their cells had rounded ends. The cells were motile by means of a polar monotrichous flagellum (Fig. 1). The seven strains examined accumulated a small number of poly- $\beta$-hydroxybutyrate granules in their cells. All 19 strains produced a yellow water-insoluble pigment in their cells, but did not produce a water-soluble fluorescent pigment on King A and B media. The surfaces of the colonies on $0.5 \%$ glucose nutrient agar were mostly smooth, but sometimes wrinkled. All 19 strains grew on MacConkey agar; 17 strains grew on SS agar. The organisms produced acid from glucose under aerobic conditions, but not under anaerobic conditions. Catalase was produced. Oxidase was not produced. Nitrate was reduced to nitrite by four strains (succinate-nitrate medium). Nitrate respiration was negative. A total of 18 strains had urease activity, and 2 strains showed DNase activity. Indole and hydrogen sulfide (TSI medium) were not produced. Hydrolysis of starch, hydrolysis of Tween 80 , hydrolysis of esculin, and hydrolysis of ONPG were not observed. Gelatin was hydrolyzed by 15 strains at $30^{\circ} \mathrm{C}$. Acid and alkaline phosphatases were not produced. Lysine and ornithine decarboxylases, phenylalanine deaminase, and arginine dihydrolase were not produced. Four strains oxidized gluconate. Good growth was observed on Simmons citrate agar (except for group Ve-2 strain KS0913). A total of 13 strains grew in medium containing $6.5 \% \mathrm{NaCl}$, and 14 strains grew at $42^{\circ} \mathrm{C}$. Methionine was not required for growth. Cleavage of protocate chuate was of the ortho type. Acid was produced from $\mathrm{L}$-arabinose, D-xylose, D-glucose, D-fructose, D-mannose, D-galactose, maltose, trehalose, inositol, mannitol, and sorbitol by all 19 strains, but not from lactose, salicin, or inulin. Acid production from other sugars and sugar alcohols differed among the strains. L-Arabinose, D-Xylose, Dglucose, D-fructose, D-mannose, D-galactose, maltose, trehalose, mannitol, acetate, gluconate, 2-keto-gluconate, succinate, $p$-hydroxybenzoate, and glutamate were utilized by all 19 strains. Lactose, raffinose, salicin, inulin, starch, and phenol were not utilized by any strain. Utilization of other carbon compounds differed among the strains. Hydrogen was not utilized by "P. lacunogenes" KS0036, KS0037, and KS0222, new isolate KS0905, and group Ve-2 strains KS0913 and KS0915.

Phenotypic characteristics of group Ve-1 strains. The five strains studied were nonsporeforming, gram-negative, rod-

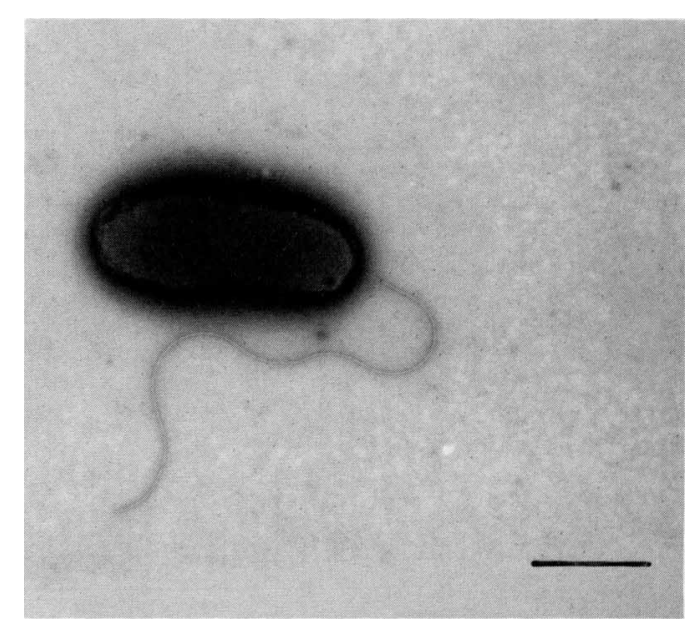

FIG. 1. Negatively stained "P. lacunogenes" KS0036 cell showing the polar monotrichous flagellum. Bar $=1.0 \mu \mathrm{m}$. 
shaped organisms measuring 0.8 to 1.0 by 1.5 to $2.5 \mu \mathrm{m}$; their cells had rounded ends. The cells were motile by means of polar multitrichous flagella (Fig. 2). Four strains accumulated a small number of poly- $\beta$-hydroxybutyrate granules in their cells. All five strains studied produced a yellow or pale yellow water-insoluble pigment in their cells, but did not produce a water-soluble fluorescent pigment on King $\mathrm{A}$ and $\mathrm{B}$ media. The surfaces of the colonies on $0.5 \%$ glucose nutrient agar were mostly smooth, rarely wrinkled. All five strains studied grew on MacConkey agar and SS agar. They produced acid from glucose under aerobic conditions, but not under anaerobic conditions. Catalase was produced. Oxidase was not produced. Four strains reduced nitrate to nitrite (succinate-nitrate medium). Nitrate respiration was negative. Four strains showed urease and DNase activities. Indole and hydrogen sulfide (TSI medium) were not produced. Hydrolysis of starch and hydrolysis of Tween 80 were not observed. Gelatin, esculin, and ONPG were hydrolyzed. Acid and alkaline phosphatases and arginine dihydrolase were produced. Lysine and ornithine decarboxylases and phenylalanine deaminase were not produced. Only strain KS0922 oxidized gluconate. Good growth was observed on Simmons citrate agar and at $42^{\circ} \mathrm{C}$. Two strains grew in medium containing $6.5 \% \mathrm{NaCl}$. Methionine was not required for growth. Cleavage of protocatechuate was of the ortho type. Acid was produced from L-arabinose, D-xylose, D-glucose, D-fructose, D-mannose, D-galactose, L-rhamnose, trehalose, inositol, mannitol, and salicin by all five strains, but not from sucrose, lactose, cellobiose, adonitol, sorbitol, or inulin. Acid production from maltose differed among the strains. L-Arabinose, D-xylose, D-ribose, D-glucose, D-fructose, D-mannose, D-galactose, maltose, trehalose, mannitol, glycerol, acetate, pyruvate, malonate, DL- $\beta$ - $n$-hydroxybutyrate, fumarate, gluconate, succinate, $p$ hydroxybenzoate, and glutamate were utilized by all five strains. Sucrose, lactose, raffinose, inulin, starch, phenol, $o$-hydroxybenzoate, and $m$-hydroxybenzoate were not utiliżed. Utilization of 2-ketogluconate differed among the strains. Hydrogen was not utilized by group Ve-1 strains KS0920 and $\mathrm{KS}_{0} 021^{\mathrm{T}}$.

DNA base composition. DNA base compositions were determined for 15 strains which were selected on the basis of their phenotypic characteristics. The DNA base composi-

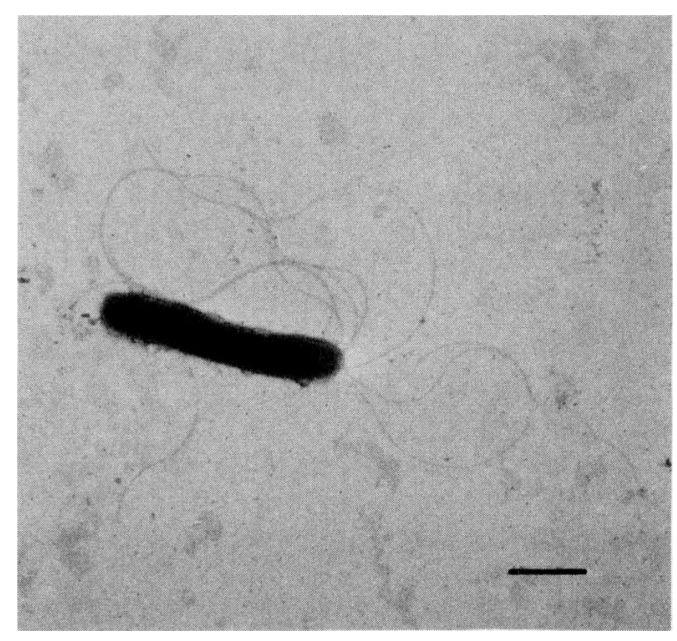

FIG. 2. Negatively stained group Ve-1 strain $\mathrm{KS} 0921^{\mathrm{T}}$ cell showing polar multitrichous flagella. Bar $=1.0 \mu \mathrm{m}$.
TABLE 3. DNA base compositions and quinone systems of " $P$. lacunogenes" strains the new isolates, group Ve-2 strains, group Ve-1 strains, and $P$. maltophilia strains

\begin{tabular}{|c|c|c|}
\hline Strain & $\begin{array}{c}\mathrm{G}+\mathrm{C} \\
\text { content } \\
(\mathrm{mol} \%)\end{array}$ & $\begin{array}{l}\text { Quinone } \\
\text { type }\end{array}$ \\
\hline "P. lacunogenes"' KS0036 & 65.1 & Q-9 \\
\hline "P. lacunogenes" KS0037 & & Q-9 \\
\hline "P. lacunogenes" KS0222 & & Q-9 \\
\hline "P. lacunogenes" KS0901 & 64.4 & Q-9 \\
\hline "P. lacunogenes" KS0903 & 63.9 & $Q \cdot 9$ \\
\hline "P. lacunogenes" KS0904 & & Q-9 \\
\hline New isolate KS0905 & & Q-9 \\
\hline New isolate KS0906 & 65.6 & Q-9 \\
\hline New isolate KS0907 & 65.4 & Q-9 \\
\hline New isolate $\mathrm{KS} 0908$ & & Q-9 \\
\hline New isolate KS0909 & 65.6 & Q-9 \\
\hline New isolate KS0910 & 65.6 & Q-9 \\
\hline New isolate KS0911 & 65.6 & Q-9 \\
\hline New isolate $\mathrm{KS} 0912$ & & Q-9 \\
\hline Group Ve-2 strain KS0913 & 64.1 & Q-9 \\
\hline Group Ve-2 strain KS0914 & & Q-9 \\
\hline Group Ve-2 strain KS0915 & 65.6 & Q-9 \\
\hline Group Ve-2 strain KS0916 & & Q-9 \\
\hline Group Ve-2 strain KS0917 & 64.9 & Q-9 \\
\hline Group Ve-1 strain KS0918 & 55.9 & Q-9 \\
\hline Group Ve-1 strain KS0919 & 55.6 & Q-9 \\
\hline Group Ve-1 strain KS0920 & & Q-9 \\
\hline Group Ve-1 strain $\mathrm{KS} 0921^{\mathrm{T}}$ & 55.4 & Q-9 \\
\hline Group Ve-1 strain KS0922 & 55.9 & Q-9 \\
\hline P. maltophilia biovar I strain $\mathrm{KS} 0001^{\mathrm{T}}$ & 65.9 & Q-8 \\
\hline P. maltophilia biovar II strain KS0194 & 64.6 & Q-8 \\
\hline
\end{tabular}

tions of the " $P$. lacunogenes" strains, the new isolates, and the group $\mathrm{Ve}-2$ strains ranged from 63.9 to $65.6 \mathrm{~mol} \% \mathrm{G}+\mathrm{C}$. The DNA base compositions of the group Ve-1 strains ranged from 55.4 to $55.9 \mathrm{~mol} \% \mathrm{G}+\mathrm{C}$ (Table 3).

Cellular fatty acid composition. All of the strains studied contained large amounts of even-numbered straight-chain $\mathrm{C}_{18: 1}$ acid, $\mathrm{C}_{16: 0}$ acid, and $\mathrm{C}_{16: 1}$ acid. Small amounts of even-numbered straight-chain $C_{12: 0}$ acid, $C_{14: 0}$ acid, and $C_{18: 0}$ acid were also detected. The hydroxy acids detected were 3-OH- $\mathrm{C}_{10: 0}$ acid, 3-OH- $\mathrm{C}_{12: 0}$ acid, and 2-OH- $\mathrm{C}_{12: 0}$ acid (Table 4). $P$. maltophilia biovar I strain $\mathrm{KS} 0001^{\mathrm{T}}$ and $P$. maltophilia biovar II strain KS0194 contained large amounts of iso- $C_{15: 0}$ acid, anteiso- $\mathrm{C}_{15: 0}$ acid, $\mathrm{C}_{16: 1}$ acid, and $\mathrm{C}_{16: 0}$ acid (Table 5).

Quinone systems. All of the strains had a ubiquinone Q-9 system (Table 3). P. maltophilia biovar I strain $\mathrm{KS} 000 \mathrm{1}^{\mathrm{T}}$ and $P$. maltophilia biovar II strain KS0194 had a ubiquinone Q-8 system.

Cytochrome difference spectra. None of the strains studied showed absorption at 551 to 554 and 522 to $524 \mathrm{~nm}$. On the other hand, $P$. aeruginosa $\mathrm{KS} 0025^{\mathrm{T}}$, which produced oxidase, showed absorption at 553 and $523 \mathrm{~nm}$ (Table 6 and Fig. 3 and 4). According to Stanier et al. (27), these spectral features are characteristics of type $c$ cytochromes. The results of the cytochrome difference spectrum and oxidase tests revealed that none of the strains studied produced cytochrome $c$ oxidase.

\section{DISCUSSION}

The " $P$. lacunogenes" strains, new isolates, group Ve-2 strains, and group Ve-1 strains are nonsporeforming, gramnégative, polarly flagellated, rod-shaped organisms and produce acid from glucose only under aerobic conditions. They produce catalase and a yellow water-insoluble pigment in their cells. Therefore, the "P. lacunogenes" strains, new 
TABLE 4. Cellular fatty acid compositions of "P. lacunogenes" strains, the new isolates, group Ve-2 strains, and group Ve-1 strains ${ }^{a}$

\begin{tabular}{|c|c|c|c|c|c|c|c|c|c|c|c|c|c|c|}
\hline \multirow{2}{*}{ Strain } & \multicolumn{9}{|c|}{ Straight-chain acids } & \multicolumn{2}{|c|}{$\begin{array}{l}\text { 3-Hydroxy } \\
\text { acids }\end{array}$} & \multirow{2}{*}{$\begin{array}{c}12: 0 \\
\text { 2-Hydroxy } \\
\text { acid }\end{array}$} & \multirow{2}{*}{$\begin{array}{c}17: 0 \\
\text { Cyclo- } \\
\text { propane } \\
\text { acid }\end{array}$} & \multirow{2}{*}{$\begin{array}{l}\text { Unknown } \\
\text { peak }\end{array}$} \\
\hline & 12:0 & 13:0 & 14:0 & 15:0 & $16: 0$ & $16: 1$ & $18: 0$ & $18: 1$ & 19:0 & 10:0 & $12: 0$ & & & \\
\hline "P. lacunogenes" KS0036 & $3.6^{\mathrm{b}}$ & & $\mathbf{T}$ & & 26.5 & 16.5 & 1.7 & 41.8 & & 5.5 & 1.6 & 3.1 & $\mathrm{~T}$ & \\
\hline "P. lacunogenes" KS0037 & 2.2 & & $\mathbf{T}$ & & 25.0 & 18.7 & 1.1 & 42.0 & & 6.3 & 1.8 & 2.8 & & \\
\hline "P. lacunogenes"' KS0222 & 4.0 & 1.2 & $\mathrm{~T}$ & $\mathrm{~T}$ & 25.5 & 19.0 & 1.5 & 38.8 & & 4.5 & 1.2 & 3.4 & & $\mathrm{~T}$ \\
\hline "P. lacunogenes" KS0901 & 3.9 & & $\mathbf{T}$ & $\mathrm{T}$ & 29.0 & 23.1 & 1.5 & 33.0 & 1.5 & 1.6 & 2.1 & 3.4 & & \\
\hline "P. lacunogenes" KS0903 & 3.9 & 1.7 & $\mathbf{T}$ & 1.1 & 29.8 & 14.9 & 3.7 & 18.9 & 11.7 & 5.2 & 3.5 & 5.2 & & $\mathrm{~T}$ \\
\hline "P. lacunogenes" KS0904 & 5.0 & 1.0 & $\mathrm{~T}$ & 0.7 & 30.0 & 16.0 & 2.3 & 26.4 & 8.8 & 3.4 & 1.8 & 4.2 & & $\mathrm{~T}$ \\
\hline New isolate KS0905 & 3.9 & & $\mathrm{~T}$ & & 26.2 & 17.0 & $\mathrm{~T}$ & 44.2 & & 2.0 & 2.5 & 3.8 & & \\
\hline New isolate KS0906 & 2.4 & & & & 27.9 & 15.3 & 1.5 & 43.1 & & 3.4 & 2.3 & 4.1 & & \\
\hline New isolate KS0907 & 3.6 & & $\mathrm{~T}$ & & 26.6 & 15.5 & 1.3 & 45.2 & & 3.4 & 1.5 & 2.5 & & \\
\hline New isolate KS0908 & 4.6 & & $\mathrm{~T}$ & & 29.4 & 18.5 & 2.8 & 30.0 & 3.4 & 3.9 & 4.4 & 2.7 & & \\
\hline New isolate KS0909 & 3.6 & & $\mathrm{~T}$ & $\mathrm{~T}$ & 29.4 & 15.7 & 1.3 & 41.1 & & 1.2 & 2.4 & 4.4 & & \\
\hline New isolate KS0910 & 4.2 & & $\mathrm{~T}$ & & 26.0 & 16.6 & 1.2 & 43.6 & & 3.5 & 1.5 & 3.1 & & \\
\hline New isolate KS0911 & 4.3 & & $\mathrm{~T}$ & & 29.0 & 15.0 & 1.2 & 42.0 & & 2.3 & 2.1 & 4.0 & & \\
\hline New isolate KS0912 & 3.4 & & & & 27.9 & 16.0 & 1.3 & 42.2 & & 5.1 & 1.3 & 2.8 & & \\
\hline Group Ve-2 strain KS0913 & 5.7 & & & & 26.5 & 14.1 & 1.4 & 44.4 & & 3.2 & 1.5 & 3.2 & & \\
\hline Group Ve-2 strain KS0914 & 3.0 & & $\mathrm{~T}$ & & 29.0 & 16.0 & $\mathrm{~T}$ & 42.6 & & 1.9 & 2.4 & 4.4 & & \\
\hline Group Ve-2 strain KS0915 & 4.2 & & & & 21.6 & 20.0 & $\mathrm{~T}$ & 46.9 & & 2.5 & 1.5 & 2.9 & & \\
\hline Group Ve-2 strain KS0916 & 2.5 & 2.8 & & 1.8 & 26.6 & 13.2 & 1.0 & 43.2 & & 3.2 & 1.1 & 3.2 & & 1.4 \\
\hline Group Ve-2 strain KS0917 & 3.2 & 0.6 & $\mathrm{~T}$ & $\mathrm{~T}$ & 23.4 & 20.9 & 0.8 & 40.0 & & 5.5 & 1.4 & 3.6 & & $\mathrm{~T}$ \\
\hline Group Ve-1 strain KS0918 & 3.7 & & 2.3 & & 25.3 & 14.4 & 1.9 & 42.1 & & 5.7 & 2.0 & 2.6 & & \\
\hline Group Ve-1 strain KS0919 & 4.0 & & 1.8 & & 27.0 & 14.8 & 1.5 & 43.0 & & 3.3 & 1.9 & 2.7 & & \\
\hline Group Ve-1 strain KS0920 & 4.9 & $\mathbf{T}$ & 1.4 & $\mathbf{T}$ & 31.7 & 15.6 & 1.8 & 37.8 & $\mathrm{~T}$ & 5.2 & 0.8 & 2.4 & & $T$ \\
\hline Group Ve-1 strain $\mathrm{KS} 0921^{\mathrm{T}}$ & 3.9 & 1.2 & 1.7 & $\mathrm{~T}$ & 27.2 & 16.6 & 2.1 & 34.8 & 4.6 & 4.6 & 1.1 & 2.4 & & $\mathrm{~T}$ \\
\hline Group Ve-1 strain KS0922 & 3.1 & 0.9 & 1.4 & $\mathrm{~T}$ & 21.0 & 18.7 & $\mathrm{~T}$ & 43.6 & & 6.9 & 1.3 & 2.3 & $\mathrm{~T}$ & \\
\hline
\end{tabular}

a The retention times of the straight-chain acids relative to the retention time of straight-chain $\mathrm{C}_{16: 0}$ acid (defined as 1.00 ) were as follows: $\mathrm{C}_{12: 0}$ acid, $0.45 ; \mathrm{C}_{13: 0}$ acid, $0.51 ; \mathrm{C}_{14: 0}$ acid, $0.63 ; \mathrm{C}_{15: 0}$ acid, $0.75 ; \mathrm{C}_{16: 1}$ acid, $1.09 ; \mathrm{C}_{18: 0}$ acid, $1.69 ; \mathrm{C}_{18: 1}$ acid, 1.85; and $\mathrm{C}_{19: 0}$ acid, 2.40. The relative retention times of 3-OH- $\mathrm{C}_{10: 0}$ and $3-\mathrm{OH}-\mathrm{C}_{12: 0}$ acids were 0.64 and 1.08 , respectively. The relative retention times of 2-OH-C $\mathrm{C}_{12: 0}$ and $\mathrm{C}_{17: 0}$ cyclopropane acids were 0.68 and 1.39 , respectively. The relative retention time of the unknown peak was 1.18 .

${ }^{b}$ Percentage of the total acids. T, Acid present at a concentration of less than $0.5 \%$.

isolates, group Ve-2 strains, and group Ve-1 strains belong to the genus Pseudomonas or the genus Xanthomonas. They do not produce oxidase. Therefore, they share a unique taxonomic position. $P$. maltophilia and the strains in the genus Xanthomonas differ from the "P. lacunogenes" strains, new isolates, group Ve-2 strains, and group Ve-1 strains in cellular fatty acid composition and ubiquinone system; namely, the major cellular fatty acids of $P$. maltophilia and Xanthomonas species are iso and anteiso branched-chain fatty acids $(15,21,22)$, and the quinone systems of these species are ubiquinone Q-8 systems $(5,15$, 32). In addition, xanthomonadins commonly found in
Xanthomonas species (2) were not found in a " $P$. lacunogenes" strain and a group Ve-1 strain (unpublished data). Moreover, the " $P$. lacunogenes" strains, new isolates, group Ve-2 strains, and group Ve-1 strains clearly differ from the yellow pseudomonads, Pseudomonas flava and Pseudomonas palleronii. The former are oxidase negative and do not utilize hydrogen, whereas the latter are oxidase positive and utilize hydrogen. The hydroxy fatty acids of the "P. lacunogenes" strains, new isolates, group $\mathrm{Ve}-2$ strains, and group $\mathrm{Ve}-1$ strains are $3-\mathrm{OH}-\mathrm{C}_{10: 0}$ acid, 3-OH- $\mathrm{C}_{12: 0}$ acid, and 2-OH- $\mathrm{C}_{12: 0}$ acid, whereas the hydroxy fatty acid of $P$. flava is $3-\mathrm{OH}-\mathrm{C}_{10: 0}$ acid and the hydroxy fatty

TABLE 5. Cellular fatty acid compositions of $P$. maltophilia biovar I strain KS0001 ${ }^{\mathrm{T}}$ and $P$. maltophilia biovar II strain KS0194 ${ }^{a}$

\begin{tabular}{|c|c|c|c|c|c|c|c|c|c|c|c|c|c|c|c|c|c|c|c|}
\hline \multirow{2}{*}{ Strain } & \multicolumn{6}{|c|}{ Straight-chain acids } & \multicolumn{7}{|c|}{ Branched-chain acids } & \multicolumn{4}{|c|}{ 3-Hydroxy acids } & \multirow{2}{*}{$\begin{array}{l}\text { iso-11:0 } \\
\text { 2-hydroxy } \\
\text { acid }\end{array}$} & \multirow{2}{*}{$\begin{array}{l}\text { 17:0 Cyclo- } \\
\text { propane } \\
\text { acid }\end{array}$} \\
\hline & $14: 0$ & $15: 0$ & $16: 0$ & $16: 1$ & 18:0 & $18: 1$ & $\begin{array}{l}\text { iso- } \\
11: 0\end{array}$ & $\begin{array}{l}\text { iso- } \\
13: 0\end{array}$ & $\begin{array}{l}\text { iso- } \\
14: 0\end{array}$ & $\begin{array}{l}\text { iso- } \\
15: 0\end{array}$ & $\begin{array}{c}\text { anteiso- } \\
15: 0\end{array}$ & $\begin{array}{l}\text { iso- } \\
16: 0\end{array}$ & $\begin{array}{l}\text { iso- } \\
17: 1\end{array}$ & $\begin{array}{l}\text { iso- } \\
11: 0\end{array}$ & $\begin{array}{l}\text { iso- } \\
12: 0\end{array}$ & $12: 0$ & $\begin{array}{l}\text { iso- } \\
13: 0\end{array}$ & & \\
\hline $\begin{array}{l}\text { P. maltophilia } \\
\text { biovar I } \\
\text { strain } \\
\mathrm{KS}^{2} 001^{\mathrm{T}}\end{array}$ & $4.8^{\mathrm{b}}$ & 3.5 & 14.8 & 10.1 & 0.8 & 0.7 & 3.0 & 0.7 & 1.0 & 35.8 & 10.8 & 1.9 & 4.9 & 2.7 & & 1.5 & 2.3 & $\mathrm{~T}$ & 0.6 \\
\hline $\begin{array}{l}P . \text { maltophilia } \\
\text { biovar II } \\
\text { strain } \\
\text { KS0194 }\end{array}$ & 3.5 & 5.2 & 9.0 & 11.0 & $\mathrm{~T}$ & $\mathrm{~T}$ & 5.1 & $\mathrm{~T}$ & 1.2 & 25.6 & 6.7 & 7.3 & 7.9 & 5.2 & $\mathrm{~T}$ & 8.2 & 1.6 & $\mathrm{~T}$ & 2.0 \\
\hline
\end{tabular}

$a$ The retention times of the straight-chain acids relative to the retention time of straight-chain $\mathrm{C}_{16: 0}$ acid (defined as 1.00 ) were as follows; $\mathrm{C}_{14: 0}$ acid, $0.63 ; \mathrm{C}_{15: 0}$ acid, $0.75 ; \mathrm{C}_{16: 1}$ acid, $1.09 ; \mathrm{C}_{18: 0}$ acid, $1.69 ;$ and $\mathrm{C}_{18: 1}$ acid, 1.85 . The relative retention times of the branched-chain acids were as follows: iso- $\mathrm{C}_{11: 0}$ acid, 0.38 ; iso- $C_{13: 0}$ acid, 0.47 ; iso- $C_{14: 0}$ acid, 0.57 ; iso- $C_{15: 0}$ acid, 0.71 ; anteiso- $C_{15: 0}$ acid, 0.75 ; iso- $C_{16: 0}$ acid, 0.85 ; and iso- $C_{17: 1}$ acid, 1.23 . The relative retention times of 3-hydroxy acids were as follows: 3-OH-iso- $\mathrm{C}_{11: 0}$ acid, $0.70 ; 3-\mathrm{OH}$-iso- $\mathrm{C}_{12: 0}$ acid, $0.88 ; 3-\mathrm{OH}-\mathrm{C}_{12: 0}$ acid, 1.09; and 3-OH-iso- $\mathrm{C}_{13: 0}$ acid, 1.13 . The relative retention times of 2-OH-iso- $\mathrm{C}_{11: 0}$ and $\mathrm{C}_{17: 0}$ cyclopropane acids were 0.50 and 1.39 , respectively.

${ }^{b}$ Percentage of the total acids. T, Acid present at a concentration of less than $0.5 \%$. 
TABLE 6. Wavelengths of the main absorption peaks in the cytochrome difference spectra of the " $P$. lacunogenes" strains, the new isolates, group Ve-2 strains, group Ve-1 strains, and $P$. aeruginosa

\begin{tabular}{|c|c|c|c|c|c|c|}
\hline \multirow{3}{*}{ Strain } & \multicolumn{6}{|c|}{ Wavelength (nm) } \\
\hline & \multicolumn{3}{|c|}{$\alpha$-Bands for cytochrome type: } & \multicolumn{2}{|c|}{$\begin{array}{l}\beta \text {-Bands for } \\
\text { cytochrome type: }\end{array}$} & \multirow{2}{*}{$\begin{array}{c}\text { Principal } \\
\text { soret } \\
\text { band }\end{array}$} \\
\hline & $a$ & $b$ & $c$ & $b$ & $c$ & \\
\hline "P. lacunogenes" KS0036" & $-{ }^{a}$ & 562 & - & 530 & - & 428 \\
\hline "P. lacunogenes" KS0037 & - & 562 & - & 530 & - & 429 \\
\hline "P. lacunogenes" KS0222 & - & 559 & - & 530 & - & 427 \\
\hline "P. lacunogenes" KS0901 & - & 559 & - & 530 & - & 426 \\
\hline "P. lacunogenes" KS0903 & - & 561 & - & 528 & 一 & 427 \\
\hline "P. lacunogenes" KS0904 & - & 560 & - & 528 & - & 427 \\
\hline New isolate KS0905 & - & 562 & - & 530 & - & 428 \\
\hline New isolate KS0906 & - & 560 & - & 530 & - & 428 \\
\hline New isolate KS0907 & - & 561 & - & 530 & - & 428 \\
\hline New isolate KS0908 & - & 562 & - & 530 & - & 429 \\
\hline New isolate KS0909 & - & 560 & - & 530 & - & 425 \\
\hline New isolate KS0910 & - & 560 & - & 530 & - & 428 \\
\hline New isolate KS0911 & - & 560 & - & 530 & - & 428 \\
\hline New isolate KS0912 & - & 560 & - & 530 & - & 426 \\
\hline Group Ve-2 strain KS0913 & - & 561 & - & 531 & - & 430 \\
\hline Group Ve-2 strain KS0914 & - & 560 & - & 528 & - & 426 \\
\hline Group Ve-2 strain KS0915 & - & 560 & - & 528 & - & 427 \\
\hline Group Ve-2 strain KS0916 & - & 561 & - & 531 & - & 430 \\
\hline Group Ve-2 strain KS0917 & - & 558 & - & 528 & - & 427 \\
\hline Group Ve-1 strain KS0918 & 一 & 560 & - & 528 & - & 428 \\
\hline Group Ve-1 strain KS0919 & - & 561 & - & 530 & - & 430 \\
\hline Group Ve-1 strain KS0920 & - & 560 & - & 528 & - & 428 \\
\hline Group Ve-1 strain $\mathrm{KS} 0921^{\mathrm{T}}$ & - & 561 & - & 530 & - & 430 \\
\hline Group Ve-1 strain KS0922 & - & 561 & - & 528 & - & 427 \\
\hline P. aeruginosa $\mathrm{KS} 0025^{\mathrm{T}}$ & - & 560 & 553 & 530 & 523 & 426 \\
\hline
\end{tabular}

${ }^{a}$-, No peak.

acid of $P$. palleronii is 3-OH-C $\mathrm{C}_{8: 0}$ acid (22). Furthermore, $P$. flava and $P$. palleronii have ubiquinone Q-8 systems (32).

For these reasons, the "P. lacunogenes" strains, new isolates, group Ve-2 strains, and group Ve-1 strains are considered to be two new Pseudomonas species, as described below.

As mentioned above, the six " $P$. lacunogenes" strains, the eight new isolates, and the five group Ve-2 strains showed the same phenotypic and chemotaxonomic characteristics. Therefore, these bacteria are members of the same taxon. On the other hand, the five group Ve-1 strains are clearly distinguished from the " $P$. lacunogenes" strains, new isolates, and group Ve-2 strains by phenotypic and chemotaxonomic characteristics (Table 7). The DNA base compositions of the group Ve-1 strains are lower than the base compositions of the other strains in the genus Pseudomonas (23). Some of the differential characteristics between group Ve-2 and group Ve-1 have been described previously by Gilardi et al. (6), Tatum et al. (30), and Weaver et al. (31).

Goresline (7) reported that " $P$. lacunogenes" decomposed agar, but our isolates and the group Ve-2 strains did not decompose agar. Moreover, at present the strains which were used for the description of " $P$. lacunogenes" are not available from culture collections or other sources. Considering the phenotypic and chemotaxonomic characteristics and the historical background of " $P$. lacunogenes" and group Ve-2, we propose to establish a new species, Pseudomonas oryzihabitans, for these bacteria. In the same manner, we propose to establish a new species, Pseudomonas luteola, for the group Ve-1 strains.

Description of Pseudomonas oryzihabitans Kodama, Kimura, and Komagata sp. nov. Pseudomonas oryzihabitans (o. ry. $\mathrm{zi}^{\prime}$ ha. bi. tans. L. fem. n. oryza rice; L. fem. adj. habitans inhabiting; M. L. fem. adj. oryzihabitans rice inhabiting) cells are rods 0.8 by $2.0 \mu \mathrm{m}$ and have rounded ends. The cells occur singly, rarely in pairs, and are motile by means of a polar monotrichous flagellum (Fig. 1). Granules of poly- $\beta$-hydroxybutyrate do not accumulate in the cells. Endospores are not formed. Gram negative.

Colonies on $0.5 \%$ glucose nutrient agar are smooth or wrinkled, entire or erose, flat to convex, light yellow, and 2 $\mathrm{mm}$ in diameter after 2 days of incubation at $30^{\circ} \mathrm{C}$. A pellicle is formed on the surface of $0.5 \%$ glucose nutrient broth. A water-insoluble yellow pigment is produced. No watersoluble fluorescent pigment is produced. Growth occurs on MacConkey agar and SS agar.

Metabolism is strictly respiratory. Oxidative, but not fermentative. Catalase is produced. Oxidase is not produced. Nitrate is reduced to nitrite (succinate-nitrate medium). Nitrate respiration is negative. Urease is produced. Indole and hydrogen sulfide are not produced. Starch, Tween 80, esculin, and ONPG are not hydrolyzed. Gelatin is not hydrolyzed. Acid and alkaline phosphatases, lysine and ornithine decarboxylases, phenylalanine deaminase, and arginine dihydrolase are not produced. Gluconate is not oxidized. Good growth occurs on Simmons citrate agar. Growth occurs in medium containing $6.5 \% \mathrm{NaCl}$. Growth occurs at $42^{\circ} \mathrm{C}$. Methionine is not required for growth. Cleavage of protocatechuate is of the ortho type. Agar is not decomposed. Acid is produced from L-arabinose, D-xylose, Dglucose, D-fructose, D-mannose, D-galactose, maltose, trehalose, mannitol, sorbitol, and inositol oxidatively, but not from L-rhamnose, sucrose, lactose, cellobiose, adonitol, salicin, or inulin. L-Arabinose, D-xylose, D-ribose, Dglucose, D-fructose, D-mannose, D-galactose, maltose, 


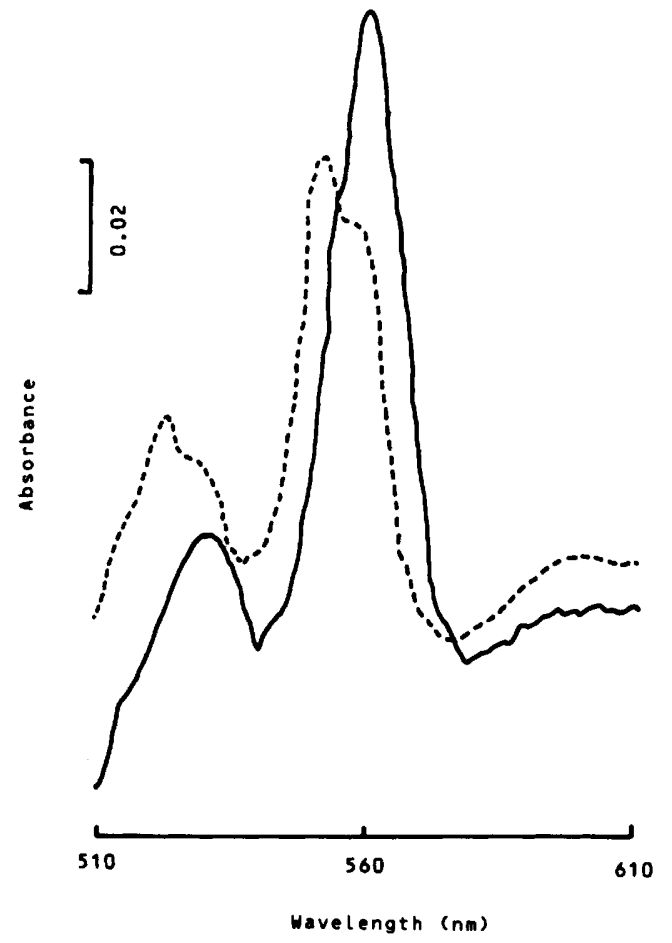

FIG. 3. Cytochrome difference spectra of " $P$. lacunogenes" KS0036 (solid line) and $P$. aeruginosa $\mathrm{KS} 0025^{\mathrm{T}}$ (dashed line).

trehalose, mannitol, glycerol, acetate, pyruvate, malonate, DL- $\beta$ - $n$-hydroxybutyrate, fumarate, gluconate, 2-ketogluconate, succinate, $p$-hydroxybenzoate, and glutamate are utilized, but sucrose, lactose, raffinose, inulin, starch, phenol, $o$-hydroxybenzoate, and $m$-hydroxybenzoate are not utilized. Hydrogen is not utilized.

The DNA base composition is $65.1 \mathrm{~mol} \% \mathrm{G}+\mathrm{C}$ (as determined by the thermal denaturation method).

The cellular fatty acids consist of large amounts of evennumbered straight-chain $\mathrm{C}_{18: 1}$ acid, $\mathrm{C}_{16: 0}$ acid, and $\mathrm{C}_{16: 1}$ acid, and small amounts of even-numbered straight-chain $C_{12: 0}$ acid, 3-OH- $\mathrm{C}_{10: 0}$ acid, 3-OH- $\mathrm{C}_{12: 0}$ acid, and 2-OH- $\mathrm{C}_{12: 0}$ acid.

The ubiquinone is ubiquinone Q-9.

The cytochrome difference spectra do not show absorption at 551 to 554 and 522 to $524 \mathrm{~nm}$.

The type strain is strain KS0036 (= L-1 = AJ $2197=$ IAM $1568=$ JCM 2592), which was isolated from a rice paddy by Iizuka and Komagata in 1963.

The description given above is based on the characteristics of type strain KS0036, and variations in the characteristics among the strains of the species are shown in Tables 1 through 4 and 6.

Description of Pseudomonas luteola Kodama, Kimura, and Komagata sp. nov. Pseudomonas luteola (lu. te' o. la. L. dim. adj. luteola yellowish) cells are rods 0.8 by $2.5 \mu \mathrm{m}$ and have rounded ends. The cells occur singly, rarely pairs, and are motile by means of polar multitrichous flagella (Fig. 2). A small number of poly- $\beta$-hydroxybutyrate granules accumulate in the cells. Endospores are not formed in the cells. Gram negative.

Colonies on $0.5 \%$ glucose nutrient agar are smooth or wrinkled, entire or erose, flat or convex, light yellow or pale yellow, and $3 \mathrm{~mm}$ in diameter after 2 days of incubation at $30^{\circ} \mathrm{C}$. A pellicle is formed on the surface of $0.5 \%$ glucose nutrient broth. A water-insoluble yellow pigment is pro- duced. No water-soluble fluorescent pigment is produced. Growth occurs on MacConkey agar and SS agar.

Metabolism is strictly respiratory. Oxidative, but not fermentative. Catalase is produced. Oxidase is not produced. Nitrate is reduced to nitrite (succinate-nitrate medium). Nitrate respiration is negative. Urease and DNase are produced. Indole and hydrogen sulfide are not produced. Starch and Tween 80 are not hydrolyzed. Gelatin, esculin, and ONPG are hydrolyzed. Acid and alkaline phosphatases and arginine dihydrolase are produced. Lysine and ornithine decarboxylases and phenylalanine deaminase are not produced. Gluconate is not oxidized. Good growth occurs on Simmons citrate agar. Growth does not occur in medium containing $6.5 \% \mathrm{NaCl}$. Good growth occurs at $42^{\circ} \mathrm{C}$. Methionine is not required for growth. Cleavage of protocatechuate is of the ortho type. Agar is not decomposed. Acid is produced from L-arabinose, D-xylose, D-glucose, Dfructose, D-mannose, D-galactose, L-rhamnose, maltose, trehalose, mannitol, inositol, and salicin oxidatively, but not from sucrose, lactose, cellobiose, adonitol, sorbitol, or inulin. L-Arabinose, D-xylose, D-ribose, D-glucose, Dfructose, D-mannose, D-galactose, maltose, trehalose, mannitol, glycerol, acetate, pyruvate, malonate, DL- $\beta-n$ hydroxybutyrate, fumarate, 2-ketogluconate, gluconate, succinate, $p$-hydroxybenzoate, and glutamate are utilized, but sucrose, lactose, raffinose, inulin, starch, phenol, $o$ hydroxybenzoate, and $m$-hydroxybenzoate are not utilized. Hydrogen is not utilized.

The DNA base composition is $55.4 \mathrm{~mol} \% \mathrm{G}+\mathrm{C}$ (as determined by the thermal denaturation method).

The cellular fatty acids consist of large amounts of evennumbered straight-chain $C_{18: 1}$ acid, $C_{16: 0}$ acid, and $C_{16: 1}$ acid, and small amounts of even-numbered straight-chain $C_{12: 0}$ acid, 3-OH-C $\mathrm{C}_{10: 0}$ acid, 3-OH-C $\mathrm{C}_{12: 0}$ acid, and 2-OH-C $\mathrm{C}_{12: 0}$ acid.

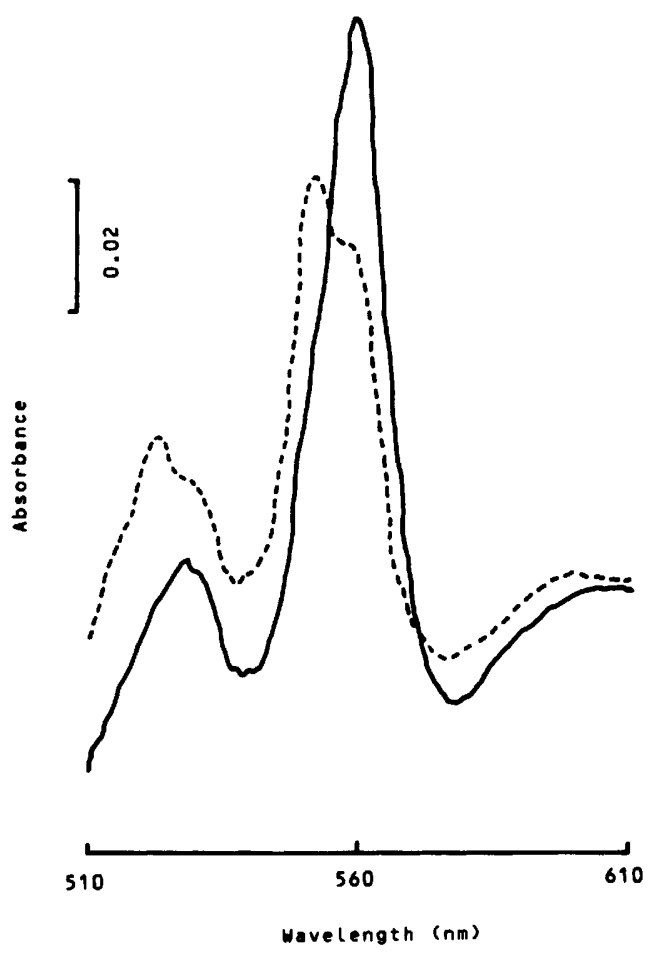

FIG. 4. Cytochrome difference spectra of group Ve-1 strain $\mathrm{KS} 0921^{\mathrm{T}}$ (solid line) and $P$. aeruginosa $\mathrm{KS} 0025^{\mathrm{T}}$ (dashed line). 
TABLE 7. Differential characteristics for $P$. oryzihabitans and $P$. luteola

\begin{tabular}{|c|c|c|c|c|c|c|c|}
\hline \multirow[b]{2}{*}{ Species } & \multirow[b]{2}{*}{ Flagellation } & \multirow{2}{*}{ Phosphatase } & \multirow{2}{*}{$\begin{array}{c}\text { Arginine } \\
\text { dihydrolase }\end{array}$} & \multirow{2}{*}{$\begin{array}{l}\text { Hydrolysis } \\
\text { of esculin }\end{array}$} & \multicolumn{2}{|c|}{ Acid production from: } & \multirow{2}{*}{$\begin{array}{l}\mathrm{G}+\mathrm{C} \\
\text { content } \\
(\mathrm{mol} \%)\end{array}$} \\
\hline & & & & & Salicin & Sorbitol & \\
\hline P. oryzihabitans & Polar, monotrichous & - & - & - & - & + & $63.9-65.6$ \\
\hline P. Iuteola & Polar, multitrichous & + & + & + & + & - & $55.4-55.9$ \\
\hline
\end{tabular}

The ubiquinone is ubiquinone Q-9.

The cytochrome difference spectra do not show absorption at 551 to 554 and 522 to $524 \mathrm{~nm}$.

The type strain is strain KS0921 (= Gilardi 4239 = IAM $13000=\mathrm{JCM} 3352$ ), which was isolated from a clinical specimen by G. L. Gilardi.

The description given above is based on the characteristics of type strain KS0921, and variations in the characteristics among the strains of the species are shown in Tables 1 through 4 and 6 .

\section{ACKNOWLEDGMENTS}

We thank T. Fujii (National Institute of Genetics Mishima, Japan) for supplying rice paddy cultures and G. L. Gilardi (Department of Laboratory, Hospital for Joint Diseases and Medical Center, New York, N.Y.) for supplying cultures.

\section{LITERATURE CITED}

1. Baird-Parker, A. C. 1963 . A classification of micrococci and staphylococci based on physiological and biochemical tests. J. Gen. Microbiol. 30:409-427.

2. Bradbury, J. F. 1984. Genus II. Xanthomonas Dowson 1939, p. 199-210. In N. R. Krieg (ed), Bergey's manual of systematic bacteriology, vol. 1. The Williams \& Wilkins Co., Baltimore.

3. Burdon, K. L. 1946. Fatty material in bacteria and fungi revealed by staining dried, fixed slide preparations. J. Bacteriol. 52:665-678.

4. Christensen, W. B. 1946. Urea decomposition as a means of differentiating Proteus and Paracolon cultures from each other. J. Bacteriol. 52:461-466.

5. Collins, M. D., and D. Jones. 1981. Distribution of isoprenoid quinone structural types in the bacteria and their taxonomical implications. Microbiol. Rev. 45:316-354.

6. Gilardi, G. L., S. Hirschl, and M. Mandel. 1975. Characteristics of yellow-pigmented nonfermentative bacilli (groups $\mathrm{Ve}-1$ and Ve-2) encountered in clinical bacteriology. J. Clin. Microbiol. 1:384-389.

7. Goresline, H. E. 1933. Studies on agar-digesting bacteria. J. Bacteriol. 26:435-457.

8. Haynes, W. C. 1951. Pseudomonas aeruginosa-its characterization and identification. J. Gen. Microbiol. 5:939-950.

9. Hucker, G. J., and H. C. Conn. 1923. Method of Gram staining. Technical Bulletin 93. New York State Agricultural Experiment Station, Ithaca.

10. Hugh, R., and L. Gilardi. 1974. Pseudomonas, p. 250-269. In E. H. Lennette, E. H. Spaulding, and J. P. Truant (ed), Manual of clinical microbiology, 2nd ed. American Society for Microbiology, Washington, D. C.

11. lizuka, H. 1960. Microflora of rice paddy. Nihon Shokuhin Eiseigaku Zasshi 1:17-29.

12. Iizuka, H., and K. Komagata. 1963. Pseudomonas isolated from rice, with special reference to the taxonomical studies of chromogenic group of genus Pseudomonas. (On the studies of microorganisms of cereal grain, part 3.) Nippon Nogei Kagaku Kaishi 37:71-76.

13. Iizuka, H., and K. Komagata. 1963. An attempt at grouping of the genus Pseudomonas. J. Gen. Appl. Microbiol. 9:73-82.
14. Ikemoto, S., H. Kuraishi, K. Komagata, R. Azuma, T. Suto, and H. Murooka. 1978. Cellular fatty acid composition in Pseudomonas species. J. Gen. Appl. Microbiol. 24:199-213.

15. Ikemoto, S., K. Suzuki, T. Kaneko, and K. Komagata. 1980. Characterization of strains of Pseudomonas maltophilia which do not require methionine. Int. J. Syst. Bacteriol. 30:437-447.

16. Katoh, K., and S. Suzuki. 1979. Microflora of manured soil. Bull. Natl. Inst. Agric. Sci. Ser. B 30:73-137.

17. Kodaka, H., A. Y. Armfield, G. L. Lombard, and V. R. Dowell, Jr. 1982. Practical procedure for demonstrating bacterial flagella. J. Clin. Microbiol. 16:948-952.

18. Komagata, K. 1961. Differentiation of genus Pseudomonas and related aerobic bacteria. J. Gen. Appl. Microbiol. 7:282-299.

19. Marmur, J., and P. Doty. 1962. Determination of the base composition of deoxyribonucleic acid from its thermal denaturation temperature. J. Mol. Biol. 5:109-118.

20. Möller, V. 1955. Simplified test for some amino acid decarboxylases and for the arginine dihyrolase system. Acta Pathol. Microbiol. Scand. 36:158-172.

21. Moss, C. W., S. B. Samuels, J. Liddle, and R. M. McKinney. 1973. Occurrence of branched-chain hydroxy fatty acids in Pseudomonas maltophilia. J. Bacteriol. 114:1018-1024.

22. Oyaizu, H., and K. Komagata. 1983. Grouping of Pseudomonas species on the basis of cellular fatty acid composition and the quinone system with special reference to the existence of 3-hydroxy fatty acids. J. Gen. Appl. Microbiol. 29:17-40.

23. Palleroni, N. J. 1984. Genus I. Pseudomonas Migula 1894, p. 141-199. In N. R. Krieg (ed.), Bergey's manual of systematic bacteriology, vol. 1. The Williams \& Wilkins Co., Baltimore.

24. Saito, H., and K. Miura. 1963. Preparation of transforming deoxyribonucleic acid by phenol treatment. Biochim. Biophys. Acta 72:619-629.

25. Sierra, G. 1957. A simple method for detection of lipolytic activity of microorganisms and some observations on the influence of contact between cells and fatty substrates. Antonie van Leeuwenhoek J. Microbiol. Serol. 23:15-22.

26. Skerman, V. B. D., V. McGowan, and P. H. A. Sneath (ed). 1980. Approved lists of bacterial names. Int. J. Syst. Bacteriol. 30:225-420.

27. Stanier, R. Y., N. J. Palleroni, and M. Doudoroff. 1966. The aerobic Pseudomonas: a taxonomic study. J. Gen. Microbiol. 43:159-271.

28. Swings, J., P. De Vos, M. van den Mooter, and J. De Ley. 1983. Transfer of Pseudomonas maltophilia Hugh 1981 to the genus Xanthomonas as Xanthomonas maltophilia (Hugh 1981) comb. nov. Int. J. Syst. Bacteriol. 33:409-413.

29. Tamaoka, J., Y. Katayama-Fujimura, and H. Kuraishi. 1983. Analysis of bacterial menaquinone mixture by high performance liquid chromatography. J. Appl. Bacteriol. 54:31-36.

30. Tatum, H. W., W. H. Ewing, and R. E. Weaver. 1974. Miscellaneous gram-negative bacteria, p. 270-294. In E. H. Lennette, E. H. Spaulding, and J. P. Truant (ed.), Manual of clinical microbiology, 2nd ed. American Society for Microbiology, Washington, D. C.

31. Weaver, R. E., H. W. Tatum, and D. G. Hollis. 1972. The identification of unusual gram negative bacteria. Centers for Diseases Control, Atlanta.

32. Yamada, Y., H. Takinami-Nakayama, Y. Tahara, H. Oyaizu, and K. Komagata. 1982. The ubiquinone systems in the strains of Pseudomonas species. J. Gen. Appl. Microbiol. 28:7-12. 